\title{
The Impact of Hygiene during COVID-19 Pandemic using Wheat Bread Microparticles: From Chemical Nutrient Content, Hand Hygiene, Multiplied Microorganisms to Education for Students with Special Needs
}

\section{DOI:10.36909/jer.ASSEEE.16065}

\author{
Tryastuti Irawati Belliny Manullang ${ }^{1 *}$, Asep Bayu Dani Nandiyanto ${ }^{1}$, A. Ana ${ }^{1}$, Efri \\ Mardawati ${ }^{2}$, Ace Suryadi ${ }^{1}$, Endang Rochyadi ${ }^{1}$, Dingding Haerudin ${ }^{1}$, Evi Sukmiroh ${ }^{3}$, Juhanaini ${ }^{1}$ \\ ${ }^{1}$ Universitas Pendidikan Indonesia, Bandung Indonesia 40154 \\ ${ }^{2}$ Departemen Teknologi Industri Pangan Universitas Padjajaran, Bandung Indonesia 40154 \\ ${ }^{3}$ SLBC YPLB Cipaganti Bandung Indonesia, 40131 \\ * Corresponding author:manullang@ upi.edu
}

\begin{abstract}
This study aims to demonstrate the importance of hygiene to prevent COVID-19 pandemic towards students with special needs using wheat bread where the chemical nutrient and multiplied microorganisms on bread made from wheat microparticles are analyzed. The experiments were conducted by contaminating the wheat bread using hands cleansed washing soap, hand sanitizer, cajuput oil, and cooking oil. Then, we gave lessons about the scientific concept to students with intellectual disabilities with IQ below 70. Results of the contaminated wheat bread showed the highest colony-forming units on the given treatment which used water and cooking oil. The second highest was the dirty hands. However, for wheat bread contaminated by handwashing soap, hand sanitizer and stores in the fridge, the colony-forming unit was null. The teaching and learning process showed that this experiment helped students to maintain personal hygiene during COVID-19. The experiment successfully shifted students' perspectives because the students directly observed the process of the spoilage bread. Although it is very difficult for the students with intellectual disabilities to learn the concept of fungus, and microbe's growth on the bread, this study can open students' perception about handwashing. Therefore, implementing the experimental demonstration through an inquirybased approach in future studies should be conducted to enable students to understand more about the scientific concept.
\end{abstract}

Key words: Chemical nutrient, COVID-19, Personal hygiene, Special needs students, Wheat bread. 


\section{INTRODUCTION}

Hygiene is defined as the rules or science of cleanliness, aiming to preserve health and prevent the spread of disease, and refers to conditions or practices by which people maintain or promote good health by keeping themselves and their surroundings clean (Aiello et.al., 2008). The world is currently experiencing an unprecedented situation due to an increasing number of cases of the novel coronavirus (2019-nCoV)-infected pneumonia (NCIP) that have been identified in Wuhan since November 2019 (Li et.al., 2020). The common signs and symptoms of coronavirus- 2019 (COVID-19) infection include symptoms of acute respiratory disorders such as fever, coughing and shortness of breath (Anggraeni et al., 2020). In severe cases, COVID-19 can cause pneumonia, acute respiratory syndrome, kidney failure and even death (Tosepu et al., 2020).

Maintaining good hygiene is imperative to reduce the risk of getting infected by the virus. One of the ways is through handwashing because hands are the most commonly used body part when in contact with our environment. Handwashing is one of the most important ways to prevent the spread of illness (Hadaway, 2020) and it is an easy, inexpensive and effective way to prevent the spread of germs and keep people healthy. Handwashing also prevents cross-contamination of food at home as well as in our food processing facilities (Jennings, 2020). Therefore, keeping hands clean is a fundamental and essential step to avoid getting sick and, at the same time, limiting the transmission of the germs to others. Despite the fact that frequent and proper handwashing practices are important in preventing infection, an average person still does not wash his/her hands often or long enough (Aiello et.al., 2008).

Various studies on handwashing have been conducted including impact on the students' handwashing practices and techniques after the intervention was given (Faye, Chrysanti and Gondodiputro, 2016); school community empowerment affects to handwashing behavior among students (Solehati et al., 2017); handwashing knowledge and poor handwashing practice among students (Tamilarasi et al., 2016).

Children with intellectual disabilities are known to have severe limitations in cognitive processing (Kauffman and Hung, 2009). However, it is essential for everyone to know the importance of personal hygiene including people with intellectual disabilities in order to improve their health outcomes and quality of life, one of which is by handwashing. It is important to make handwashing as part of the culture and habit especially since the world is 
currently facing an unprecedented time due to the COVID-19 pandemic outbreak (Razon, 2020), besides, handwashing has also been a focus on education since the outbreak.

Handwashing as a part of personal hygiene is also included in the curriculum as the grooming skills for students with intellectual disabilities. Unfortunately, a number of studies have found that individuals with developmental disabilities have difficulties with grooming across all levels of functioning and ages (Mattson et.al., 2016). Therefore, this research intended to teach students with intellectual disabilities the importance of handwashing as a key component of personal hygiene and prevention towards the spread of the current COVID19 pandemic outbreak using the wheat bread, water, hand sanitizer, cajuput oil and cooking oil. Also, it is essential to enhance students' comprehension on the importance of hygiene specifically during the COVID-19 pandemic outbreak.

\section{Spoilage Bread Process}

Bread has recently been well-known in almost all parts of Indonesia especially in bigger cities. Whole wheat bread usually stays edible for two to three days. However, microbes cause bread mold. Moldy bread loses weight and changes the appearance both inside and outside, because of the mold colonies which have different colors: white, greenish, blackish, yellowish (Vagelas, et.al., 2011). Moldy bread produces fungal spores and should not be consumed as it can cause allergic and respiratory problems. On the mold, we can see the colonies of spores and the fungus reproduces.

\section{METHOD}

\section{Research Design}

The research design of this study adopted a two-pronged approach. First, an experiment design was performed by contaminating the wheat bread using hand cleansed washing soap, hand sanitizer, cajuput oil and cooking oil. Second, a single-subject observational research design among six students with mild disabilities.

\section{Study 1: An Experiment of Bread Contamination with Various Treatments of Hygiene Process}

\section{Experiment Procedures}

We made the whole wheat bread for this experiment using a bread maker. We used $35 \mathrm{~g}$ of wheat flour, $75 \mathrm{~g}$ of salt, $50 \mathrm{~g}$ of sugar, $250 \mathrm{~g}$ of high protein flour, $5 \mathrm{~g}$ of yeast, $40 \mathrm{~mL}$ of 
coconut oil and water. First, we put the flour, salt, and coconut oil in a bowl and added a reasonable amount of water and mixed them all. We beat the dough until it came together in a ball. We took the dough and made a small hole in the dough and added the yeast. After that, we put the dough inside the bread maker. Then, we selected the weight and bread skin color options button on the bread maker. The dough that we made weighed $750 \mathrm{~g}$. Next, we waited for the machine to stop and, in our experiment, it took four hours for the whole process.

To test the contamination of the wheat bread, we applied hand washing soap, hand sanitizer, cooking oil, cajuput oil to our hands, and put the wheat bread inside a resealable plastic bag. The washing soap used for this experiment was Dettol Anti-Bacterial Hand and Body soap which has an active ingredient that confers its antiseptic property is chloroxylenol $\left(\mathrm{C}_{8} \mathrm{H}_{9} \mathrm{COl}\right)$ and produced by Reckitt Benckiser. As for the hand sanitizer, we used alcohol-based Mandom hand sanitizer (alcohol=75\%) produced by PT Mandom Indonesia Tbk (TCID) and we used Fraiswell cooking oil produced by PT. Bina Karya Prima. Lastly, we used Cap Lang cajuput oil which contains pure cajuput oil produced by PT Eagle Indo Pharma.

\section{Manipulation Variables on Bread Treatment}

We conducted a bread experiment to analyze the importance of hygiene. The experiment on the bread was conducted by touching the bread with unwashed dirty hands, touching the bread after washing hands with running water, touching the bread after washing hands with soap and running water, touching the bread after washing hands and then apply hand sanitizer, touching the bread after washing hands and then apply cooking oil, touching the bread after washing hands and then apply cajuput oil and lastly storing a slice of bread in a fridge and with no treatment.

All the bread samples used as the benchmark for the experiment. After given the treatment, based on the analysis of the decomposed bread, it was found that the decay gradually happened to all bread and after six days, the wheat bread was sent to Laboratorium Sentral Universitas Padjajaran, Indonesia, to obtain data analysis on the decayed bread. There were two analysis conducted. The first one was proximate analysis to determine the nutritional value of the bread which includes water content, ash content, and protein content. The second test was Total Plate Count (TPC) to analyze the number of microbes found in the wheat bread by counting the bacterial colonies grown in the media. 


\section{Study 2: A Single-Subject Research Design Among Six Students with Mild Disabilities}

A single-subject design research then was adopted. A convenient sampling technique was used due to limited sample size in special education research (Fraenkel et al., 2011). This methodology is an appropriate method to investigate individual learning processes in special education (Donmez, and Cagiltay, 2019; Rogers and Graham (2008); Odom et al., 2003). In this single-subject design research, the data were collected from participants two times as the pre-post design.

This study used single-subject research towards six students with mild disability with IQ below 65 and one student with hearing impairment with IQ 75, with ages ranging from 16-17 years old. All students study at Sekolah Luar Biasa-C (SLB-C) in Bandung, Indonesia, which is a special school for students with intellectual disabilities. Despite studying at the higher secondary school, only three students could have sufficient reading and writing skills. Other students have challenges in reading and writing long sentences.

\section{Participants' Demographic Data}

Figure 1 shows students' cognitive, affective and psychomotor abilities. All students have varied cognitive and affective abilities but nearly all students have high psychomotor abilities. Although the students' age is between 15-17 years old, not all students have high literacy skills. Only three students can read and write and understand long sentences, while the others are able to read and write but have limited understanding of the sentences being read or written. Besides having intellectual disabilities, two students have cerebral palsy and it affects their movement and speech.

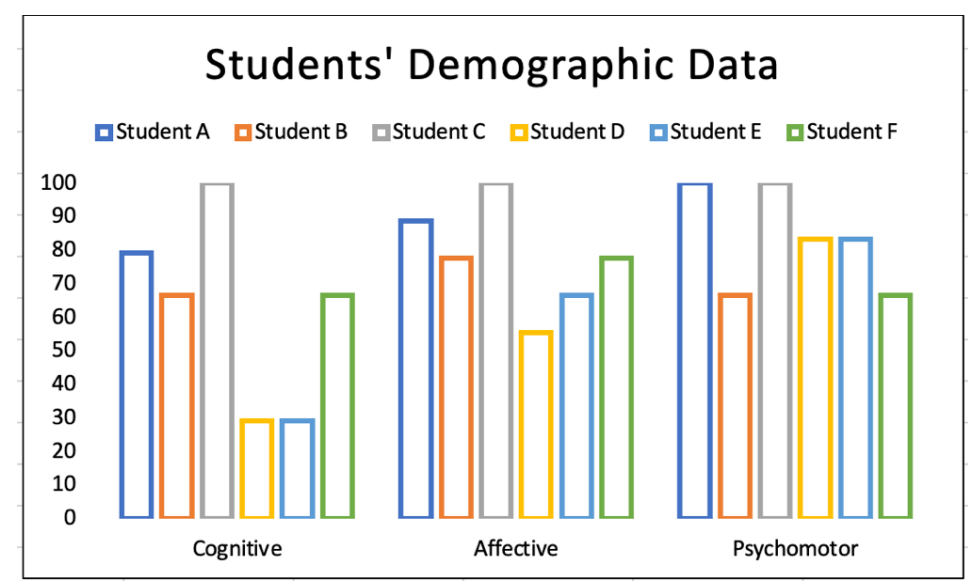

Figure 1. Participants’ Demographic Data

\section{Research Procedures}


Before designing the lesson plan of this study, we conducted an interview with the homeroom teacher. Information on Intelligent Quotient, literacy skills, numeracy skills, reasoning ability, adaptive behavior, cognitive, affective and psychomotor abilities was collected. The gathered information then used to design the lesson. However, the school is closed due to the COVID19 and distant learning is conducted. We, then, collaborated with parents and caregivers to help students with the experiment.

In brief, the teaching process was conducted in 90 minutes where the teacher recorded the explanation then sent it to the students. After that, the teacher asked students to answer the questions (pre-test). After getting the answers from the students, the teacher gave an explanation of the spoilage bread concept using the PowerPoint presentation with the recorded explanation for three minutes. At this stage, parents or caregivers were asked to join and listen to the explanation so they could support the students' learning. Teacher then asked students to answer the same questions (post-test).

\section{RESULTS AND DISCUSSION}

\subsection{Results}

\section{Study 1: Effect of Various Hygiene Process on Bread Contamination and Quality}

Figure 2 shows the mold colonies on the spoilage wheat bread after six days. The bread spoilage is categorized into two types of spoilage based on the microorganism growth and chemical reactions. Chemical or physical spoilage happens gradually, causing the bread (crumb) inside to harden and it is called staling. During the staling process, crumb porosity decreases, and the pores become smaller.

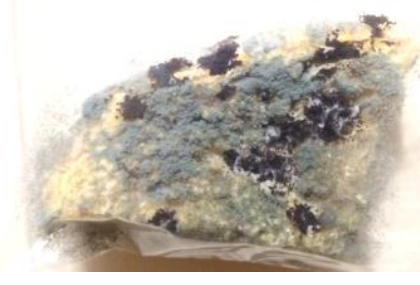

Figure 2. Mold colonies on the wheat bread

Table 1. Result of proximate analysis and Total Plate Count

\section{Test parameters}

Bread treatment
Total Plate

Count

CFU/ml 


\begin{tabular}{|c|c|c|c|c|}
\hline & $\begin{array}{l}\text { content } \\
(\%)\end{array}$ & $\begin{array}{l}\text { content } \\
(\%)\end{array}$ & $\begin{array}{l}\text { content } \\
(\%)\end{array}$ & $\begin{array}{l}\text { (Colony } \\
\text { Forming Unit) }\end{array}$ \\
\hline Store in fridge & 33.19 & 1.83 & 7.20 & 0 \\
\hline Dirty hands & 40.04 & 2.15 & 7.93 & $4.20 \times 10^{4}$ \\
\hline Wash hands using soap & 37.73 & 1.78 & 7.17 & 0 \\
\hline $\begin{array}{l}\text { Wash hands using water and hand } \\
\text { sanitizer }\end{array}$ & 42.62 & 1.96 & 7.58 & 0 \\
\hline Wash hands using water and cooking oil & 41.57 & 1.83 & 7.01 & $9.30 \times 10^{3}$ \\
\hline Wash hands using water and cajuput oil & 44.75 & 1.98 & 7.92 & $3.00 \times 10^{2}$ \\
\hline
\end{tabular}

Table 1 shows the result of proximate analysis and Total Plate Count. As for the ash content, the highest ash content is found on the wheat bread which was touched using dirty hands $(2.15 \%)$ and the lowest ash content found on wheat bread which was touched using hands washed using soap (1.78\%). Furthermore, the lowest protein level is on the bread which was touched using hands that washed using water only and added cooking oil which is $7.01 \%$ and the highest is on the bread touched using dirty hands $(7.93 \%)$ followed by using water and cajuput oil (7.92\%), using water and hand sanitizer $(7.58 \%)$, stored in the fridge $(7.20 \%)$, using soap (7.17), using water and cooking oil (7.01) respectively.

Based on the TPC test conducted, it was found that the highest colony forming unit was on the wheat bread given treatment using water and cooking oil $\left(9.30 \times 10^{3}\right)$, followed by dirty hands $\left(4.20 \times 10^{4}\right)$, and using water and cajuput oil $\left(3.00 \times 10^{2}\right)$ respectively. However, for the wheat bread given treatment with soap, hand sanitizer, and store in the fridge the colony-forming unit was null (0).

\section{Study 2: Students Comprehension}

From the study, we compared students' comprehension of teaching conditions with and without experimental demonstrations. The collected information used during the lesson. In order to simplify students' answers, all the answers are scaled from 1-4 where 4 (very good), 3 (good), 2 (quite good), 1 (need support), 0 (know nothing). The maximum score is 56, therefore, in order to get the final score, we divided the students' obtained score by the maximum score and multiplied the score to 100. Table 2 shows the question given to students and the results before and after the experimental demonstration. 
Table 2. Question given to students and the results before and after the experimental demonstration

\begin{tabular}{|c|c|c|c|}
\hline No & Questions & $\begin{array}{c}\text { Before the } \\
\text { experimental } \\
\text { demonstration }\end{array}$ & $\begin{array}{c}\text { After the } \\
\text { experimental } \\
\text { demonstration }\end{array}$ \\
\hline
\end{tabular}

1. I often wash my hands

$50 \%$

$75 \%$

2. I know why hand washing is important

$33.33 \%$

$58.33 \%$

3. I know what germs are

$12.50 \%$

$33.33 \%$

4. I know microbes are

$0 \%$

$37.50 \%$

5. I know there are germs on my hands

$37.50 \%$

$58.33 \%$

6. Washing hand using water only make my hands germs
free

$41.66 \%$

$54.16 \%$

7. Washing hand using water only and apply hand sanitizer make my hands germs free

$25 \%$

$50 \%$

8. Washing hand using soap and running water make my hands germs free

$45.83 \%$

$70.83 \%$

9. Washing hand using water only and apply cajuput oil make my hands germs free

10. Washing hand using water only and apply cooking oil make my hands germs free

11. What types of microbes appear on the bread spoilage?

$50 \%$

$50 \%$

$45.83 \%$

$41.66 \%$

12. What do you think happens if you do not wash your hands?

13. What do you think is good hand washing?

$37.50 \%$

$70.83 \%$

14. I have ever seen moldy bread

$75 \%$

$75 \%$

Table 3 shows the pretest and posttest result of the students' work before and after the experimental demonstration which shows that students have made significant progress from the experience we conducted.

Table 3. Comparison of the pretest and posttest result of the students' work before and after the experimental demonstration

\begin{tabular}{|c|c|c|c|}
\hline No & Subject & $\begin{array}{c}\text { Before giving experimental } \\
\text { demonstration }\end{array}$ & $\begin{array}{l}\text { After giving experimental } \\
\text { demonstration }\end{array}$ \\
\hline
\end{tabular}




\begin{tabular}{llll}
\hline 1 & Student A & $39.28 \%$ & $53.57 \%$ \\
2 & Student B & $32.14 \%$ & $46.42 \%$ \\
3 & Student C & $39.28 \%$ & $67.85 \%$ \\
4 & Student D & $33.92 \%$ & $48.21 \%$ \\
5 & Student E & $32.14 \%$ & $48.21 \%$ \\
6 & Student F & $37.50 \%$ & $57.14 \%$ \\
\hline
\end{tabular}

\subsection{Discussion}

Food with high water content will result in faster spoilage than food with low water content (Winarno, 2005). According Standar Nasional Indonesia (SNI) 01-3840-1995, the highest ash content on bread is $1 \%$. The ash content of all the bread after given treatment exceeds the maximum limit set by SNI. Furthermore, the protein content in bread is determined by the type of flour used (Pusuma et al., 2018).

From the analysis, we can conclude that the wheat bread which was touched using dirty hands has higher water content, ash content and protein content. The wheat bread which was touched after washing hands with water and applied cooking oil has the highest microbes. Despite washing hands using soap, applying hand sanitizer, or applying cajuput oil, all the bread exceeds the maximum limit of ash content in a food product. Therefore, from this analysis, we showed our students that doing proper handwashing is a must in order to stay hygienic.

From the experiment we found that the main bread-spoilage microorganisms are molds, from the Rhizopus, Aspergillus, Pennicilium, and Eurotium groups. In the experiment, the bread which was contaminated and stored in the fridge was sent to the laboratory and analyzed. Table 1 shows the result of proximate analysis and Total Plate Count. Based on the results of the analysis, the highest water content is found at the wheat bread given treatment using water and cajuput oil (44.75\%), followed by using water and hand sanitizer $42.62 \%$ ), using water and cooking oil (41.57\%), dirty hands (40.04\%), using soap (37.73\%) and store in the fridge $(33.19 \%)$ respectively.

\subsubsection{Teaching Results}

Students could observe the fungus and its types and the process of the bread spoilage after the students see the presentation. This can be seen from the results of students' pretest and posttest 
results. Children with intellectual disabilities are known to have deficits in cognitive processing (Kauffman and Hung, 2009), therefore, the lesson towards the students was carefully discussed with the teacher. Table 2 shows the pretest and posttest results and the questions given to the students. We discussed the topic with the teacher, contacted parents, shared the topic and materials needed for the lesson, and then discussed it with the parents. As schools are closed and learning happens at home, parents play dual roles as both parents and teachers.

\subsubsection{Understanding in The Importance of Personal Hygiene}

The results showed that students had a varied understanding of handwashing. From the pretest given, it was found that all students had washed their hands because at the earlier stage of the COVID-19 pandemic outbreak, parents and teachers had encouraged and reminded them to wash hands. Prior to our experiment, the teacher had given a lesson on how to wash their hands properly. Based on this study we conducted using whole wheat bread, we found out that learning the importance of hygiene specifically washing hands to students with intellectual disabilities is achievable.

Table 3 shows that the students made progress in understanding the personal hygiene and the chemical nutrient and the multiplied microorganisms. Student $\mathrm{C}$ made significant progress up to $67.85 \%$ upon given the presentation about the wheat bread spoilage and personal hygiene (as confirmed in Figure 2). Student $C$ had the highest IQ among the students although the student had hearing impairment but had sufficient reading abilities. Student A obtained $53.57 \%$, student B achieved $46.42 \%$, students D and E got a maximum score of $48.21 \%$ and student $\mathrm{F}$ obtained $57.14 \%$.

From the data in Table 3 student B had the lowest score. Student B had the lowest IQ among the students and student B also had communication difficulties. Although students with intellectual disabilities are known to have an IQ that ranges from 50 to 70, we found that all students make progress in understanding personal hygiene. When students improve their knowledge on what microbes and germs are, it helps them to become more aware of the importance of washing their hands frequently. They also know that washing hands using soap is the best method to kill the germs on their hands compared to washing hands only with water and only applying hand sanitizer. This has also resulted in students' improvement in washing hands at home. Based on the interview with parents after two weeks of the learning, it was found that all students washed their hands more often than before. 
Furthermore, students could justify why they need to wash their hands although they used simple and short sentences such as the germs are a source of disease, washing hands to eliminate viruses or getting stomach ache. They could give justification after the students were given explanations using PowerPoint Presentation. Students made progress in understanding the topic and personal hygiene as seen in Table 1. Besides, we found that it is very difficult for the students with intellectual disabilities to learn that fungi and microbes grow on the bread. Students could answer the questions with support from parents and the teacher. As seen in Table 1, the lowest progress happened on the question regarding the microbes on the spoilage bread. As Algahtani (2017) stated that when it comes to challenges in intellectual functioning, learning is a slow process because people with intellectual disabilities find it hard to recall, generalize activities and skills, and they are less motivated.

However, conducting a further study on teaching and learning the chemical nutrient, multiplied microorganisms on bread made from microparticles wheat, and how it impacts hygiene through inquiry-based approach could be conducted to the create opportunities for students to do the experiment themselves because conducting experimental demonstration for students with mild intellectual disabilities need help in improving students' understanding on the concept being taught (Maryanti et al., 2020). Pair work or group work, scaffolding the lesson, repeating the core questions are possible effective approaches and methods to teach students with intellectual disabilities to comprehend difficult concepts (Manullang et al., 2020). As this was the first experiment that students and the teacher experienced, we found that these concepts are new to students. Therefore, repetitive learning activities on the chemical nutrient multiplied by microorganisms on bread made from wheat microparticles, and how it impacts hygiene would be impactful and beneficial to students, teachers, and parents.

In addition, limitations to this study should be noted. First, the learning was conducted at home with support from parents. Therefore, the progress that students made might be affected by the parents' support. Second, the bread used was self-made bread for this research. Third, handwashing soap, the hand sanitizer, and the cajuput oil brand might affect the result of proximate analysis and Total Plate Count. An important implication of our study derives from our finding on the abilities of students to understand the concept of personal hygiene and the changing process of the bread which relates to scientific concepts. Future implication of this study is necessary to examine the importance of science learning to students with 
intellectual disabilities as it will improve their knowledge and information on personal hygiene.

\section{CONCLUSION}

The fungus and microbes grow on the wheat bread because of the microparticles on the bread. The chemical nutrient of the wheat bread contained water content (approximately 33-45\%), ash content (about 1.70-2.20\%), and protein content (approximately 7-8\%), which shows that wheat bread provides an excellent environment for fungus and microbes to grow. Results from the contaminated wheat bread showed the highest colony forming unit on the given treatment using water and cooking oil. Understanding the concept of personal hygiene through the wheat bread experiment is interesting for students because they could see the changing process of the bread. Although students cannot mention the fungus and microbes' names on the bread, however, they know that it is important for them to wash their hands to keep their bodies clean and to reduce the bacterial infection. A scientific topic can be taught to students with mild intellectual disabilities, regardless of their IQ level and they were capable of learning the chemical nutrient, multiplied microorganisms on bread made from wheat microparticles and how it impacts hygiene. Students have been washing hands more often in order to avoid the COVID-19 pandemic upon learning the importance of personal hygiene from the demonstration given. This study contributes to better understanding of handwashing among students with intellectual disabilities. Furthermore, implementing the experimental demonstration through an inquiry-based approach gives opportunities to students to conduct the experiment themselves and is helpful to enable students to understand more about the scientific concept. 


\section{ACKNOWLEDGEMENTS}

We would like to acknowledge RISTEK DIKTI (Grant-in-aid Penelitian Terapan Unggulan Perguruan Tinggi (PTUPT)) and Bangdos Universitas Pendidikan Indonesia.

\section{REFERENCES}

Aiello, A. E., Larson, E. L., and Sedlak, R. (2008). Personal health: Bringing good hygiene home. American Journal of Infection Control, 36(10): S152-S165.doi: 10.1016/j.ajic.2008.09.009.

Algahtani, F. (2017). Teaching students with Intellectual Disabilities: Constructivism or Behaviorism? Academic Journals, 12(21):1031-1035. Doi:10.5897/ERR2017.3366.

Anggraeni, S., Maulidina, A., Dewi, M.W., Rahmadianti, S., Rizky, Y.P.C., Arinalhaq, Z.F., Usdiyana, D., Nandiyanto, A.B.D., and Al-Obaidi, A.S.M. (2020). The Deployment of Drones in Sending Drugs and Patient Blood Samples COVID-19. Indonesian Journal of Science and Technology, 5(2): 18-25.

Donmez, M., and Cagiltay, K. (2019). Development of eye movement games for students with low vision: Single-subject design research. Education and Information Technologies, 24(1): 295-305.

Faye, C. M. C. S., Chrysanti, C., and Gondodiputro, S. (2016). Handwashing among Schoolchildren in Jatinangor, West Java. Althea Medical Journal, 3(2): 170-174.

Hadaway, A. (2020). Handwashing: Clean Hands Save Lives, Journal of Consumer Health on the Internet, 24(1): 43-49, DOI: 10.1080/15398285.2019.1710981.

Jennings, A. J. Hand Sanitizing Station. (2020). United States Patent. https://patentimages.storage.googleapis.com/be/34/0e/39df8d365dbe77/US10660983.pdf.

Kauffman, J. M., and Hung, L.-Y. (2009). Special Education for Intellectual Disability: Current Trends and Perspectives. Current Opinion in Psychiatry, 22(5): 452-456. doi:10.1097/YCO.0b013e32832eb5c3.

Li, Q., Guan, X., Wu, P., Wang, X., Zhou, L., Tong Y. et al. (2020). Early Transmission dynamics in Wuhan, China, of Novel Coronavirus-Infected pneumonia. The New England Journal of Medicine 382 (January):1199-1207. 
Manullang, T.I.B., Rakhmat, C., Haerudin, D., Rochyadi, E., Nandyanto, A.B.D., Muspita, R., and Sumiroh, E. (2020). Teaching Photochemical using Hydrillia Verticillata to Students with Intellectual Disabilities. International Journal of Psychosocial Rehabilitation, 24 (8):3640-3657.

Maryanti, R., Hufad, A., Nandiyanto, A.B.D., and Sunardi. (2020). Understanding Covid19 Particle Contagion through Aerosol Droplets for Students with Special Needs. Journal of Engineering Science and Technology, 15(3):1909-1920.

Mattson J.M.G., Roth M., and Sevlever M. (2016). Personal Hygiene. In: Luiselli J. (eds) Behavioral Health Promotion and Intervention in Intellectual and Developmental Disabilities. Evidence-Based Practices in Behavioral Health, pp.43-72. Springer, Cham. https://doi.org/10.1007/978-3-319-27297-9_3.

Odom, S. L., Brown, W. H., Frey, T., Karasu, N., Lee Smith-Canter, L., and Strain, P. S. (2003). Evidence-based practices for young children with autism: Contributions for single-subject design research. Focus on autism and other developmental Disabilities, 18(3): 166-175.

Pusuma, D.A., Praptiningsih, Y., and Choiron, M. (2018). Karakteristik Roti Tawar Kaya Serat yang Disubstitusi Menggunakan Tepung Ampas Kelapa. Jurnal Agroteknologi, 12(1): 29-42.

Razon, B. C. (2020). COVID 19: Impetus for "Community Spirits" among Filipinos. Indonesian Journal of Science and Technology, 5(2): 26-33.

Rogers, L. A., and Graham, S. (2008). A meta-analysis of single subject design writing intervention research. Journal of Educational Psychology, 100(4): 879.

Solehati, T., Kosasih, C. E., Susilawati, S., Lukman, M., and Paryati, S. P. Y. (2017). Effect of school community empowerment model towards handwashing implementation among elementary school students in Dayeuhkolot subdistrict. Kesmas: National Public Health Journal, 11(3):111-116.

Tamilarasi, R., Arunmozhi, R., Raja, V. K., and Rajajeyakumar, M. (2016). A study to assess the knowledge and practice of hand washing among school going adolescents in Chennai. world, 1(3):147-155. 
Tosepu, R., Gunawan, J., Effendy, D., Ahmad, L., Lestari, H., Bahar, H., and Asfian, P. (2020). Correlation between weather and Covid-19 pandemic in Jakarta, Indonesia. Science of The Total Environment, 725 (2020):1-4. doi: 10.1016/j.scitotenv.2020.138436.

Vagelas, I., Gougoulias, N., Nedesca, E.-D., and Liviu. (2011). Bread contamination with fungus. Carpathian Journal of Food Science and Technology, 3:1-6.

Winarno, F.G. (2004). Kimia Pangan dan Gizi. Jakarta, Indonesia: Gramedia Pustaka Utama. 